\title{
The revitalization of the mapuche language as a space of ideological struggle: the case of pehuenche communities in Chile
}

\begin{abstract}
Based on our findings in a research founded by CONICYT carried out in pehuenche communities in Alto Bio, this paper proposes the use of recent perspectives in Linguistic anthropology, languages ideologies model to understand local initiatives of linguistic revitalization, such as the Bilingual intercultural education program (BIEP) in schools in the communities, as spaces of "ideological struggle", that is, social spaces in which several social actors dealing with indigenous languages and its revitalization communities and indigenous organizations, CONADI, MINEDUC, universities have diverse and heterogeneous cultural models about languages in contact (chedungun and Spanish), models that explain the problems that these and other revitalization initiatives have to confront. Thus, first we show the situation of indigenous languages in Chile and how it replicates in the case of pehuenches communities studied, we describe initiatives to revert that situation and the BIEP as one of them and finally, we present the notion of 'language ideology' and its application to analyze the dynamics of this program in the communities and to give some keys to reformulate it regarding the general indigenous reality.
\end{abstract}

Keywords: Linguistic anthropology, language ideologies, linguistic revitalization, indigenous languages, mapudungun/ chedungun
Volume I Issue 5 - 2017

\author{
Cristián Lagos, Felipe Pérez de Arce,Verónica \\ Figueroa \\ Department of Linguistics, Universidad de Chile, Chile
}

Correspondence: Cristián Lagos, Associate Professor, Department of Linguistics, Universidad de Chile, Chile,Tel 229787068,Email kinelagos@uchile.cl

Received: June 24, 2017 | Published: September 01, 2017
Abbreviations: CONICYT, corporation for research in science and technology; CONADI, national corporation for indigenous development; BIE, bilingual intercultural education; BIEP, bilingual intercultural education program; MINEDUC, ministry of education

\section{Introduction}

A while ago a researcher in public policy issues asked me a "linguistic" question. He pointed out, as he was reviewing his upcoming book, that according to his knowledge, "the word Mapuche had no plural", but the Publishing House insisted that the "correct word is Mapuches". What is fascinating about this question whether Mapuche should be pluralized following Spanish grammar or should be kept in its original form according to the indigenous language is that it encompasses keys to answer a series of issues that indigenous languages in Chile have faced and still face in contact with Spanish. The answer, which is not simply linguistic, requires an analysis that in the last decades has proven to be highly fruitful for the study and intervention of languages either indigenous or not at a worldwide scale: the studies regarding language ideologies from the linguistic anthropology standpoint ${ }^{1-4}$ and its contribution to the understanding of language planning and revitalization initiatives as an area for "ideological struggle" that requires clarification. ${ }^{5,6}$ Thus, there follows, we have proposed first to

A. Analyze the situation of the indigenous languages in Chile in terms of their functional displacement and its historical and social factors and the way in which this reality is portrayed in Pehuenche communities that still enjoy a relative isolation in the south of Chile.

B. Describe the genesis and development of a series of activities and initiatives that try to work against this process, both from the State and the indigenous civil society, the Bilingual Intercultural Education Programme (BIEP) among them.

C. Present the notion of "language ideology" and its contribution to interpret and have an impact in the development of language planning an revitalization initiatives on indigenous languages.

D. To apply this model to understand the problems and resistance that the implementation of the IBE presents in schools in Pehuenche communities in the Alto Bio commune (Trapa Trapa, Pitril and Callaqui). This analysis, at the end of the article will allow us to take up our initial question and interpret it under new a new light. Our goal is to articulate the global reality of indigenous languages in relation to their individual reality in the Pehuenche communities that we have researched, so as to go back to general considerations that could be applied to the diverse indigenous languages in the country.

\section{Materials and methods}

The results that will be presented below were obtained from an ethnographic work in the Mapuche-Pehuenche communities of Pitril and Callaqui, both belonging to the Alto Bío Bío commune, in the Bío Bío region, in the foothills of Los Andes Mountains, $220 \mathrm{~km}$ from the city of Concepción in Chile. Their localities correspond to communities mainly pehuenches (about $75 \%$ of the population is of that ethnic origin). ${ }^{7}$ Pitril has a total of 407 inhabitants, with $75 \%$ being considered of Pehuenche origin. They have a basic school with about 50 students. The other community studied is Callaqui, with a total of 637 inhabitants, $85 \%$ is considered of Pehuenche origin. It also has a basic school with about 100 students, with boarding school and like the Pitril School, has a Bilingual Intercultural Education Program, by a traditional educator of Pehuenche origin, whose mother tongue is 
chedungun. Finally, it is important to point out that the population that attends both the Pitril and Callaqui schools is not exclusively Pehuenche, also attending the sons and daughters of non-indigenous settlers living in the area, constituting, therefore, an intercultural meeting space. Participant observation and semi-structured interviews and discussion groups were conducted with

a. 3 BIEP municipal managers from this area,

b. 2 teachers working in establishments where BIEP is provided,

c. 3 traditional educators a Position of the Indigenous Language Sector and

d. 4 members of the communities of Pitril and Callaqui that belong to the Pehuenche ethnic group and are chedungun speakers.

\section{Results and discussion}

\section{The situation of the indigenous languages in Chile: the case of pehuenche communities}

The image of functional displacement in the Chilean indigenous languages, particularly Aymara and Mapudungun, in favour of Spanish has been corroborated by several authors ${ }^{8-13}$ and by the studies that we have been carrying out by Lagos. ${ }^{14-15}$ According to these antecedents, this situation displays recessive trends regarding these languages in relation to Spanish, considering the progressive displacement that they have undergone since the Pacification of the Araucanía, the annexation of the Arica y Tarapacá region and the colonization process in the southernmost tip of Chile during the XIX Century, which has been hastened and increased due to the rural-urban migration creating a generalized functional imbalance leading to the substitution of the low-prestige language (indigenous languages) by the dominant language (Spanish). This adverse scenario is not fortuitous, as it is the result of complex political, economic, military, demographic and cultural processes, ${ }^{16}$ sharing as a factor the dominance of one group over another. In the Chilean case, the development of the National State ignored the coexistence of a series of indigenous languages with Spanish and forced their speakers to take decisions about them. These decisions facilitate the displacement towards Spanish monolingualism and thus the drop in the indigenous languages vitality. This displacement is mainly produced because the speakers move between two competing languages due to their associated social ecologies. ${ }^{17}$ These dynamics, as described in previous articles, fully apply to the relationship established between indigenous languages and the Spanish language in Chile.

This situation can also be found in the dynamics the Mapuche language (known as Chedungun in these areas) faces in the Alto Bio Bio communities. During our ethnographic fieldwork, we have found a similar functional displacement in these communities, which is consistent with the findings in the phonological aspect in recent studies ${ }^{18}$ in Pehuenche children and teenagers in the same area. In this respect, we have found out that in the communities:

A. In public activities, in contact with winkas (non-Mapuche people) only Spanish is used. This can be seen in municipal, health and education facilities. Furthermore, there seems to be no choice in these spaces particularly, as there is only a few or no competent speaker of both languages. In educational facilities, low skill employees (janitors, cooks, etc.) tend to be Chedungun speakers and they use it playfully. However, no teacher is a fully competent Chedungun speaker (except for traditional educators).

B. In the organization and participation of community ritual activities, such as the nguillatun or we tripantu (Mapuche New Year), as not the whole audience is competent in Chedungun, both languages are used, with Spanish as a tool for explaining the rest what is happening. Moreover, in the privacy of each family's space during the nguillatun, interaction takes place mainly in Spanish due to the generation gap and the language lost in the new generations (children and teenagers only know a few words and phrases; most of the adults and young adults hold some passive knowledge of the language but are reluctant to teach their children and most of the elderly are coordinated bilingual speakers).

C. In the family, due to the interruption in the language transmission to the new generations (as a result of the social expectations associated to Spanish and the previous discrimination experience), only the elderly use the indigenous language. Even a tradition that encompasses culture and language, as the UY giving (native name, usually associated to a family totem animal) to the new-born babies, has gradually been lost. Thus, children enter school with their "winka üy" (Pedro, Juan, etc.) and the school has become a space for rescuing these traditional names. This is an example of the poor language reproduction within the family, which, adding acculturation agents such as the television is another element of the breakdown of the traditional language reproduction channels.

\section{Public policy and indigenous language revitalization initiatives}

Already stated the general overview of the indigenous languages in Chile and particularly in the indigenous Pehuenche communities, this second section will review in which ways the State and the indigenous communities and organizations have developed different language planning initiatives (formally and informally) and revitalization initiatives leading towards reverting the current displacement situation.

From the point of view of public policies regarding the indigenous population, although there have been and still are a series of positive discrimination initiatives towards the indigenous people, these have mainly been focused on grants as the "indigenous grant" or extra benefits given that they prove they belong to a indigenous ethnicity. All these measures are simply welfare-oriented and assimilationist, which proves and reproduces the economic, social, cultural and political asymmetry between the national society and the indigenous population. One of the many areas in which this asymmetry is expressed and that has been neglected in favour of the welfare-oriented approaches, is the cultural heritage, particularly the languages and language rights. ${ }^{19}$ This problem can be understood considering that the indigenous peoples, despite the legal changes and international legislation and norms, still have not been appropriately recognized by national and international laws as different peoples with different cultures. This would require, among other issues, to incorporate cultural, linguistic, political, economic, value-based, historical and relational variables to a complex political discussion. ${ }^{19}$ Although these communities have been the object of public policies since the establishment of NationStates, most of the governments have pushed forward assimilationist strategies preferring a series of values and principles aimed at 
strengthening a "western" perspective of development that has neither meant a larger pluralism nor an actual consideration of these peoples' differences (in fact, the language ideologies analysis in the IBE that we intend to lay forward strengthen this tendency). The linguistic dimension, therefore, has not been deaf to this general model and, certainly, since the beginning, the incorporation of Spanish as the language of education has been one of the main tools of assimilation in the past. ${ }^{20}$ Over time, these migration processes from their native territories towards the great cities during the XX century marked a turning point to understand the language planning measures in favour of the indigenous languages revitalization that have arisen since the 80 s until today. ${ }^{20-23}$ Little by little, the idea of the urban indigenous person as a social subject takes form. The subject uses its language, has been educated in urban schools and high-schools and that takes its language as a main symbolic element for its identity construction and resistance. ${ }^{14,24}$ Therefore, it is from this social basis standpoint that the first displays of interest for regulating systematically the relationship between the languages in contact comes from, mainly by indigenous people educated in the university system. Given this scenario, where indigenous languages are part of an urban society and where natives and their descendants are affected by socialization processes framed by exogenous cultures, of Enlightenment rational inspiration, indigenous languages have become an object to be thought over under new scopes. On the one hand, their interaction in a different environment demands adaptations and on the other hand, specialized university-trained intellectuals have been using Linguistics categories (such as "standardization", "intellectualization", "authority", among others) regarding the indigenous languages. ${ }^{23}$ This same influence, in terms of linguistic ideologies, has also been identified for other American Indian languages, such as Aymara ${ }^{25}$ or Maya. ${ }^{26,27}$

Thus, it is interesting that one of the first "formal" language planning initiatives ${ }^{20}$ came up in the $70^{\prime}-80^{\prime}$ ' decade of XX century from the academic world (linked to indigenous associations), with the discussions regarding the creation of a grapheme system for the Mapuche language $\mathrm{e}^{21,22}$ in the universities of Temuco and Concepción. Later, it was not until the start of the 1990s that the State took a more leading role in defining a global public policy towards the indigenous population, including marginally language aspects. ${ }^{23}$ From then until now, a public policy regarding the indigenous population has been arisen, considering language planning aspects, directly or indirectly and somehow systematically and always linked to urban organizations and communities, which could be synthesized in four different axes:

A. To establish a unified grapheme system, especially for the Mapuche language. Although it is not an initiative that has its origins in the State, CONADI promotes and finances instances to achieve this goal, typical of corpus planning, either creating their own grapheme system or, as in 2010 , promoting the creation of one through the Metropolitan Mapuche Linguistic Commission. In the case of the Mapuche language, efforts go back to the 70-80 decade.21-23 Other studies have also shown the importance of these actions on the writing of indigenous languages as a necessary step for their revitalization, such as Abarzúa25 for the Aymara case, Brody28 for the Maya and Abdelhay,29 and Kelly30 for the languages of West Africa (which demonstrates the transversality of these concerns in different and distant Indian cultural traditions, due the influence of the eurocentric vision about languages). In these studies it has also been shown how the construction of these written systems supposes different linguistic ideologies that govern them, being not neutral or "techniques" tasks, from the linguistic point of view. 31

B. To support initiatives of organizations and communities regarding the foundation of indigenous languages academies, following the framework and functions of the Royal Spanish Academy. In the case of the Mapuche language, this process has not been without difficulties, as in 2008 and linked to CONADI activities and academic centres as the University of Chile, when a series of discussions aroused regarding their legitimacy in terms of Mapuche's "collective language rights" over their own language.23 In 2013, once again, another group of indigenous associations, linked to university centres, announced the Mapuche Language Academy in Arauco.

C. To implement indigenous language workshops, mainly in urban contexts, as agents of indigenous language teaching. During the previous government (2010-2013), CONADI established as one of their priorities in the "Language and Culture" area the creation of language workshops (mainly Aymara and Mapuche) in urban contexts by financing urban organizations to take over these workshops. Around 400 workshops were created along the country.23 Furthermore, until today, there has been a series of self-financed instances from the academic world that function as language workshops.

D. Finally, to implement the Bilingual intercultural education program (BIEP) as a strategy for education for indigenous peoples in the country.32 This incentive, converge the efforts of the Ministry of Education, CONADI and urban Indian organizations and rural communities, constituting an instance in which it seeks to contribute to the knowledge and practice of indigenous languages in a space like school. It is important to note that, originally, this was not a program created to revitalize indigenous languages, but to install compensatory education for indigenous, aimed at improving its performance and possibility of upward social mobility. Furthermore, in a broader context it must be understood as a measure to reduce social tensions within multiethnic states, so as to generate stabilized social climates that ensure the arrival of foreign investors, within the rules established by multilateral institutions as the World Bank or the International Monetary Fund. Over time it has been built a discourse on the BIE which defines it as "a new pedagogical approach of revaluation and rescue of indigenous cultures as a way of coexistence between different cultures, in a logic of a pluralistic society that aims at the search for a dialogue between them " $(14: 152)$; i.e, this new method of intercultural education leads to the revitalization of indigenous peoples beginning with their language, which is both, par excellence, the symbol of their culture. This founding spirit, as we shall see later, allows understanding many of the language ideologies in conflict over the languages covered by this program, which will be the initiative to discuss in more detail based on what we could log regarding its development in our field activities in Pehuenche communities.

These initiatives are considered efforts, more or less formal and more or less explicit, of language planning, setting an area that both politically and academic, has not yet been fully developed in the country, away from other realities (e.g. Canada, USA, Mexico, Bolivia). Therefore, it its development, little attention has been paid to the non-neutral character of any language planning activity (and 
its initiatives and practices), as it tends to reflect the political and economic imperatives of particular social groups rather than language or cultural concerns per se. ${ }^{33}$ Therefore, these measures and practices are activities where policymakers, academics, intellectuals and participants of the indigenous world have guided their practices and discourses based on a series of cultural models ("language ideologies") on the Spanish language as a dominant language and indigenous languages that so far, have not been made explicit, given its nonneutral nature. This explanation is entirely necessary when analyzing the failures, difficulties and challenges of these and other activities related to the revitalization of indigenous languages. Therefore, it is important to move forward in this necessary ideological clarification as it is put forward by the Linguistic anthropology and language ideologies studies. Finally, it is important to state that such ideological clarification relates not only to cultural models with respect to the indigenous language in question Mapudungun, but also to models that are available for the other languages in contact, in this case the Spanish language, which also plays a role in defining the place of the endangered language.

\section{Language ideologies: Language revitalization as a space for ideological struggle}

Having already put forward the situation of indigenous languages and the practices of recovery and revitalization associated with them, in this section we introduce the model of "language ideologies" as a contribution to interpret and influence in the development of language planning and revitalization initiatives on indigenous languages. As noted earlier, understanding language planning (formal and informal) and language revitalization initiatives directly or indirectly derived from it, as non-neutral activities, it becomes absolute relevant to analyze the cultural models that precisely make these practices and discourses non-neutral. In this sense, it is the Linguistic anthropology, as an interdisciplinary field devoted to the study of language as a cultural resource and practice ${ }^{34}$ to establish the theoretical and methodological perspective to be taken in order to achieve this goal. Under this discipline, the notions that the speakers themselves (not necessarily with expertise from the scientific point of view) have on their language may result as significant inputs to the work of language planning, demonstrating that their notions the unskilled are as cultural and therefore as biased as the ones owned by language specialists. In this perspective, notions as 'standardization', 'intellectualization', 'authority', etc., acquire a historical and relative character and show their epistemic, economic and political commitments. Thus, in language revitalization initiatives, both from the contribution that deliver intellectuals (academics, researchers, teachers) as those delivered by indigenous leaders, participants of organizations and activists, we find a set of cultural models on indigenous languages (and the other languages in contact with them) that generally go unnoticed as part of common sense. Hence, it becomes of importance the recent developing of a field of study known as "language ideologies", widely used in studies of language contact in Europe and the United States, but only recently applied the Chilean reality and language contact. ${ }^{14,23}$ The notion of "language ideology" is the result of the evolution of the original proposals of Boas (rescuing the existence of secondary elaborations in language speakers) and BL Whorf and later of D Hymes and $\mathrm{J}$ Gumperz, in Linguistic anthropology and can be understood as a set of "beliefs, feelings and conceptions, raised explicitly or expressed in communicative practices, about the structure and use of language, which often respond to the political interests of individual speakers, ethnic groups and other interests and the National States", ${ }^{35}$ thus reflecting the social and historically situated nature of cultural models about language. Thus, they correspond to rationalizations that everyone language specialists and non-specialists- conduct on languages as cultural resources and everything that surrounds them (its functions, its structure, its speakers, etc.), cultural models that communities have built on their languages and allowing them to rationalize their use in communicative acts. Incorporating the cultural variable that involves its use allows the linguistic analysis to connect to the relations of economic and political power playing a central role in the social construction of cultural models that social actors make about everything around them, factors that become extremely important when we stand in the field of language contact. ${ }^{36}$ Following Kroskrity, ${ }^{3,35,37}$ language ideologies are characterized by

a. Representing perceptions on language according to the interests of each specific historical group,

b. Be manifold, ie, heterogeneous, even within the same community, since social experience within it is not uniform and

c. Be recognized both in discourse (explicit) and practices (implicit) of the members of a community.

The richness of this kind of analysis is shown in its many applications, to languages of different origin and status, thus covering Linguistic anthropology studies to refer to the situation of non-indigenous languages, such as English, ${ }^{38}$ Galician, ${ }^{39}$ German, ${ }^{40}$ French, ${ }^{41}$ Spanish, ${ }^{42}$ and indigenous languages, mainly from Mexico, USA, Canada and Chile. ${ }^{37,43,45}$ Furthermore, the development of this concept and its applications has advanced to a prolific application around the exploration of the role of these models in the production of social identities of various kinds (ethnic, gender, indigenous, national, etc.), including its use in situations of language displacement and revitalization. It is in this latter field that this approach has shown its main applied implications, allowing making explicit cultural models which are hidden in the discourses and practices around the revitalization of endangered languages. In this area, highly important have been the contributions of some authors, that using the model of language ideologies, have managed to uncover the historical and non-neutral nature for many of the ideas that are held on indigenous languages and their revitalization, which, sometimes may even be harmful for that purpose. This shows how, for example, Kroskrity, ${ }^{46}$ who reveals how many documentation and salvage works that linguists and anthropologists conducted in which the so called the "wild" era (marking the concern to regain folklore and oral traditions of Native American groups until the 70 's). After these attempts to rescue and preservation, as he reveals, there was a "strong covert racist and colonialist tendency", ${ }^{46}$ even when their explicit motivation was to counteract the pressure of language displacement towards English. Hill, ${ }^{5}$ meanwhile, uncovered the ideological/cultural commitments present in the rhetoric of experts (linguists, anthropologists, indigenous intellectuals and activists in general) in the defence of endangered languages, establishing at least three recurring topics regarding language ideologies, whose uncritical use could undermine such defence. These topics are:

A. the ideology about the "universal property" of endangered languages (indigenous languages as a means of wealth that we are all responsible for) whose logic is rooted in an ecological, biological and environmental design, where human beings can think of dimensions of the natural and cultural 
world as resources related to the notion of property, "one of the foundational logic that has led colonial and neocolonial projects during the last two centuries",5 enclosing, in front of the eyes of many communities, the threat of justification of expropriation of this resource by external agents, alienating endangered languages from its speakers.

B. The ideology of "hyperbolic assessment" which on an analogy between the biological and language diversity, notes language diversity as an example of cultural wealth and a "treasure" and that its use carries the risk to turn endangered languages "... rather in objects for preservation in museums sponsored by elites rather than for their daily use by imperfect human beings"5

C. The ideology of the "enumeration", through which statistics on the increasing number of languages that will disappear in the near future are used, so as to call for action to prevent it and which is based on one of the expressions of knowledge of colonial regimes, enclosing therefore, another form of domination and expression of power, through, for example, what will be considered language and what will be dialect or variety in these censuses. Meanwhile, Cameron, 6 focused on the discourse of non-specialists and the press, also points to these figures on the endangerment and extinction of languages, referring to the notion that the phrase "endangered languages" has emerged of the harmonization with the biodiversity and conservation of land resources, rather than being addressed from the standpoint of the "... political concerns about human rights, social justice and the distribution of resources between more and less powerful groups".6 Thus, the prospect of language ideologies shows the need for ideological clarification on initiatives to revitalize indigenous languages, protecting managers, implementers and beneficiary communities, from the paradoxical effect caused by the common places in the discourse of activists around indigenous languages in terms of distracting the attention of socioeconomic factors that are often involved in the situation of endangered languages. In this area, the focus of language ideologies, as stated by Kroskrity, allows us to understand "... the interaction of indigenous ideologies and imposed by the State as well as the existence of multiple ideologies within communities of ancestral languages",35 focusing on political struggles, redistribution and recognition in which many preservation and revitalization movements are inserted.6 That is why the activities of language revitalization, such as those developed around indigenous languages in Chile (in this case, Mapuche) should be considered sites of 'ideological struggle' in the sense of the multiple cultural models that are put forward, a conflict that should be made explicit so that the revitalization efforts are not hindered.

\section{The IBE in pehuenche communities: a space of ideological struggle}

Among the various triggering factors of the situation of language displacement found in the studied Pehuenche communities, some of them can be considered as the connectivity with urban life, the arrival of satellite TV, the pervasiveness of evangelical creed, the association between the access to material and symbolic goods of modern life and the Spanish language, the experience of discrimination in the past, many mothers leaving home to become salaried workers in Ralco,
Santa Barbara and Los Angeles, among others. However, once this break in the transmission and use of Chedungun within the family has already been installed, communities have been provided the school with a special significance as an agent in the recovery of the use and knowledge of Chedungun, playing a role in the rebuilding of this lost circuit. So the question is: is it possible to fulfill this role in a context like this? The answer this, it is necessarily to resolve before another question, namely, can an indigenous language be taught in the framework of an institution of Enlightenment rational roots like school? The answers to these and other concerns point as the question that began this article, what are the language ideologies of social actors of this program (students, teachers, principals, communities, the Ministry, etc.) regarding what is language and languages (Chedungun, Spanish and others), cultural models, as we shall see, may conflict, allowing us to understand and explain many of the difficulties experienced by the initiative not only in Alto Bio Bio, but in the different indigenous contexts urban and rural in which it occurs. ${ }^{45}$ Therefore, these local ideologies are connected, as we shall see, with broader ones, which may be found in other experiences of revitalization that we have studied (as the case of the formation of an academy of the Mapuche language) and some indigenous intellectuals and activists on this issue. ${ }^{23}$

\section{The language as an object of formal teaching: the conception of language from the "Western" point of view}

From the "Course of General Linguistics" by Ferdinand de Saussure (and all the functionalist tradition in linguistics that has followed, linguists have taken for granted that language is an entity (an object) having existence beyond the individual will. ${ }^{47,48}$ Linguistics, in fact, has been commissioned to strengthen this reified character through the construction of an epistemic icon: the "system", which describe, analyze and make tangible through the creation of Grammar, Phonology, etc. In this sense, this reified image of language as an object outside ourselves, is something unproblematic. Following this vision there is a certain conception of the nature of language, which comes from the rationalist Greco-Roman tradition, as it is assumed that this comes from a rational agreement between individuals to attach things to words. Thus, modern linguistics has erected a cultural model about language and languages -a language ideology- as a rational mechanism and intersubjective reality external to us and that every individual in their everyday life cannot and will not change. Therefore, it does not create any problem to be taught in a certain way in certain contexts and for certain agents and, like other social institutions; we simply use it or behave in accordance with it.

Thus, those who have been socialized in a Enlightenment rational cultural matrix (whose central themes are the ideas of Progress, Reason and Education) have no problem understanding that grammars and dictionaries contain "what a language is", what exists or not in it and what is right or wrong in it, being the canon on which they rely to speak it, defining its appropriate uses. Nor is it difficult to understand that there are "experts" that are validated to be an authoritative voice with regard to this social order and in light of this, they indicate how to speak it or which forms must be acquired. In the case of Spanish, the creation of the Royal Academy of the Spanish Language in 1713, with the mission of "... fix the words of the Spanish language on its major elegance, property and pureness....", was the highest grade of formalization of this notion of a reified language, consecrating a group of specialists who are responsible for the custody, care and 
cultivation of this appliance. Later, with the rise of modern linguistics, from the early nineteenth century and especially in the early twentieth century, the image of the language specialist became a fact of the cause that no one questions, joining the academic validity with the scientific. For its part, language teachers (English, Spanish, etc.) in schools are empowered to act as experts, as they have the double back under their university education, which defines the ways in which this device must be transmitted and learned by new generations, relying on a textual production that further legitimizes this objectification (grammars, teaching manuals, etc.).

The end result of this social construct that we have as a society about the language and languages, both from the cultural construction made by science and the academic world, as well as from the level of the specific practices in the learning of languages in formal instruction, we can identify the following as the coordinates that define a certain ideology of language in societies built around an Enlightenment rational cultural matrix, understanding that language is a cultural object that (a) is a system, which immediately reduces its proximity from us and turns it into an object (it de-subjectivize it), being reduced to a compendium of rules, taxonomies and categories; (b) it is learned and its use modulated by experts (academics, linguists) who know it fully and give us their true forms, experts that are legitimized as they participate in a knowledge society based on criteria of historical and scientific authority; and (c) its external existence is further enhanced by becoming concrete through the written production through dictionaries and compendiums of grammar, phonology and semantics.

\section{Indigenous language ideologies about the language: conflicts regarding its teaching in school}

What has been described in the previous point it could be understood as part of common sense we have regarding our languages. However, when we make contact with languages and speakers that have been socialized in other historical traditions not Enlightenment rational such as members of the Pehuenche communities described here, we face other cultural logics on how to build social knowledge about a cultural object such as language, cultural patterns that reveal immediately the historical character of our conception of it and open new possibilities and keys to raise adequate measures to promote the teaching of minority languages and to generate programs to improve their social and political status in multilingual contexts. ${ }^{45}$ The axes that define this specific linguistic theory about language Chedungun are the following ones:

\section{Chedungun comes from the earth/nature}

As other researchers have reported for other indigenous languages, $3,4,39,41$ we have found that Chedungun speakers have a nonexternal reified conception of their language, which puts into question all our Western notions of ownership and authority over language. According to this language ideology, the rational Enlightenment idea of a contractual and conventional nature of language does not exist, not being part of a rational pact between people, but directly connected with nature, stemming from it, as a Pehuenche person from the community of Callaqui states: “... in Chedungun all things, words, names. Ehh ... Place names come from something, from nature ... if you look at nature, you see many things, many things to come and that is what is being conveyed to us all. Then the elders learned to speak Chedungun that way" (... en el chedungun, todas las cosas, palabras, apellidos. Ehh... Nombres de lugares vienen de algo, de la naturaleza... si uno observa la naturaleza uno ve hartas cosas, muchas cosas que pueden venir, que es lo que nos está transmitiendo, todo eso. Entonces los ancianos de esa forma aprendieron a hablar chedungun) (LP).

According to Chedungun speakers and members of the communities, their native language is part of nature, is a force over nature "... along with all the others that are part of the world" (CD), which already marks a significant distance with a rational and reified conception of it. Also, it would be rooted in a rather naturalist thesis about the origin of language, which, in turn, is related to the same form conceived as a community, that is, as people of the land, as stated by another speaker: "For example, path in Chedungun is said rüpü, but rü ... rüpü. So when I say rü. The word comes for example; when you're walking you make a sound (onomatopoeia of walking on dirt road). So there you have rüpü. So these are words that come from nature, because they are sounds man make when walking on the ground. Then it comes from that concept. And all the other words in Chedungun come from something" (Por ejemplo, camino. En chedungun se dice rüpü, pero rü... rüpü. Entonces cuando yo digo rü. La palabra viene por ejemplo, uno cuando camina emite un sonido (onomatopeya de caminar sobre camino de tierra). Ahí tienes rüpü. Entonces son palabras que vienen de la naturaleza, porque son sonidos que emite el hombre cuando camina sobre la tierra. Entonces viene de ese concepto. Y todas las otras palabras del chedungun vienen de algo) (AC).

This naturalistic conception of the origin of their language is also projected to its current functional dimension, while the Chedungun "would serve" to speak in the natural, historical environment of this community, but not for the city, which is the new environment in which is predominantly inhabiting by a good proportion of the Mapuche people who have migrated. As an urban Mapuche person expressed it by stating that their language "would not serve to speak in the cement":

“... in another place where there is no environment like this I think that ... hard to speak ... I don't know. I should not. I do not know if you could, because there is much ... much noise for example. For example, Chedungun needs calm, quiet, relaxation on what one is going to speak (...) That's why our parents chose the afternoons, till eight p.m. (...) Because at that time the sound of nature turns off completely, it is total silence " (... en otro lugar donde no haiga un entorno así tampoco yo creo que... difícil de hablar... No sé. No debería. No sé si se podría, porque hay mucho... mucho por ejemplo un ruido por ejemplo. Por ejemplo el chedungun se necesita calma, silencio, relajación en lo que uno va a hablar (...) Por eso, los papás de nosotros elegían las tardes, de la tarde hasta como la ocho de la noche (...) Porque a esa hora ya el sonido de la naturaleza se apaga, totalmente es silencio")(IR).

This is a warning to the designers and makers of public policy in terms of adapting the curriculum and textbooks to these native cultural models. Another implication of this language ideology in the practice of traditional educators and students in schools and communities is that since the Chedungun comes from nature, the principle which states that "learning the system the language is learned" is put into question, constituting a source of conflict and resistance. This notion, under which for some people it is impossible for anyone who is not Mapuche or does not live in the natural environment to learn the language:

"But if Chedungun is spoken, through ... They have to know the ... the kimün or wisdom left to us, because in order to speak Chedungun 
one must have knowledge, advice or a story. EPEW for example, a story and to speak Chedungun, I think when grownup, you'll never learn to speak Chedungun. And that is something that will always happen. They will learn words in Chedungun, but beyond that, to speak correctly as English or that thing. Learning to teach, English is learned, but not Chedungun, because there are people that speak English properly. But if you want to speak Chedungun properly, you won't. "(Pero si el chedungun se habla, a través de... Tienen que conocer el... el kimün o la sabiduría que a nosotros nos dejaron, porque para hablar chedungun uno tiene que tener conocimiento, un consejo o alguna historia. Epew por ejemplo, cuento. Y para hablar chedungun, yo creo que después de grande nunca van a aprender a hablar chedungun. Y eso es algo que siempre va a pasar. Van a aprender palabras en chedungun, pero más allá hablar correctamente como el inglés o esa cosa. Aprender a enseñar. El inglés se aprende, pero en chedungun no se aprende, porque hay personas que hablan inglés correctamente. Pero si usted quieren hablar chedungun correctamente no van a hablar correctamente) (LP).

\section{Chedungun as a way of life}

In interviews conducted in Santiago, a Mapuche woman, educated at university and therefore trained in Linguistics (Spanish teacher), summarized as follows his vision of the Mapuche language, trying to reassert their status as "a language": “... Mapudungun is a language, properly speaking and in that sense it has its linguistic features, in this case, morphological, it allows to name the reality we belong to" (... el mapudungun es una lengua, ya, con todas sus letras y que en ese sentido con sus procedimientos lingüísticos, en este caso, morfológico, permiten nominar la realidad de la cual estamos insertos) (SC).

However, when we analyzed the view of non-trained in university education Mapuche people, especially in communities in isolated rural contexts isolated as described herein, it is clear how such a view corresponds to the projection of a cultural model of language that is not neutral but that it is actually framed in the "ideology of the standard language". ${ }^{2}$ Understanding that for Pehuenche people their language has not emerged from a social, rational contract, but it is an asset given by the ñuke mapu (Mother Earth), the representation of it as an entity that is not separated from life itself is a necessary step, that is, not as a reified system but, as they say, a "way of life", something that pervades their existence, something that differentiates it from other languages of the Enlightenment rational sphere, which is defined as kimün: “... I have a question. The Mapuche language, Chedungun, is the talk of the earth, thus from there we learned it, how can you prevent that our language becomes a simple language and not a lifestyle, a way of life? ..." (... me surge una duda. El mapuche, el chedungun, es el habla de la tierra, y de ahí nosotros lo aprendimos, ¿cómo evitar que nuestro idioma se transforma en un simple idioma y no en una forma de vida, una manera de vivir?...) (MN).

And considering the Chedungun as part of Mapuche Kimün it moves it further away from the western notion that for speaking a language it is enough to know the system, because it cannot be dissociated from the set of cultural knowledge that defines the Mapuche-pehuenche as belonging to their community: “... If one prefers not to speak Mapudungun, I think we wouldn't feel Mapuche anymore (...) the Mapuche people are everywhere (...) and if don't speak the language, that is, even wearing the clothing, one feels a brother (...) and even more so if we speak the language. " (... si uno no prefiere hablar en mapuche yo creo que ya no nos sentiríamos mapuches (...) los mapuches estamos en todas partes (...) y si no lo habláramos, o sea, uno ve siquiera con la vestimenta se siente hermano (...) y con mayor razón si hablamos la lengua) (L.M.).

Which is also made clear in the statement made by one of the traditional educators in the area: “.... it is not compatible with the Western where you go to a language class and learn language and then you go home, or you learn from a book ... Chedungun comes from very deep from something very important. But you say that Chedungun is just to talk" (.... no es compatible con la visión occidental en que uno va a un curso y aprende lengua y luego se va a su casa, o la aprende en un libro... el chedungun viene de muy... de muy profundo... de algo muy importante. Entonces, ustedes dicen que el chedungun es hablarlo no más) (LP).

Now, if they understand that their language is part of their ethnic identity and that this, in turn, is rooted in its close link with nature or ñuke mapu, it is not surprising that there is a resistance to influences that may come from other languages (primarily the official language of Chile, Spanish), whether in an ontological sense “... they clearly felt that if they wrote this in Spanish it would lose much of its force and even its truth." AR or from the point of view, resistance to the socio-political domination. This derives into an attitude that can go against the possibility of learning the language as a system, under the system of formal education, through books, workshops and teachers: "All the texts I've seen, by universities, academies - by non-Mapuche people - are made with Castillian logic. A person who learns that way, will not be able to speak, because we have our own logic to speak and this logic is in Mapudungun" (Todos los textos que yo he visto, por las universidades, las academias-por gente no-mapuche-están hechas con lógica castellana. Una persona que aprende así, no va a poder hablar, porque nosotros tenemos nuestra propia lógica para hablar, y esta lógica está en Mapudungun) (AD).

Thus, another consequence of this language ideology in the practice of agents tied to the IBE in the classroom of the communities has to do with the resistance of educators around the possibility of moving the teaching of something that is not a system but a 'way of life', into a classroom: “... We have to teach Mapudungun in a classroom, but we also have to take our students, hopefully, to hear the river and feel the mountain and try to understand the birds. The culture is steeped in stories of animals, mountains and in our culture, everything that exists is alive. All elements in nature also converse with us. There are deep values to be taught in a language teaching methodology. We cannot remain content with having children in a classroom. You have to know about the mountains, about the rivers, about the animals, about the birds, you need to know how to protect nature, we must know how to pray to the earth" (... tenemos que enseñar el mapudungun en una sala, pero tenemos que llevar a nuestros estudiantes ojalá también a escuchar el rio y a sentir la montaña y a tratar de entender los pájaros. La cultura está impregnada de historias de animales, de montañas, y en nuestra cultura, todo lo que existe tiene vida. Todos los elementos que están en la naturaleza también dialogan con nosotros. Hay valores profundos que hay que enseñar en una metodología de enseñanza de idiomas. No podemos quedarnos contentos con tener a los niños en una sala de clase. Hay que saber de montañas, hay que saber del rio, hay que saber de animales, hay que saber de pájaros, hay que saber proteger la naturaleza, hay que saber rogar a la tierra) (EL).

In addition, according to another traditional educator, there is an incompatibility between these values of Chedungun and the Western 
teaching format, noting that: “.... the model of the class, the teacher and his books does not help me. Chedungun must be taught as was done in communities, in contact with nature, in conversation, by the fire..." (... el modelo de la clase, del profesor y sus libros no me sirve. El chedungun hay que enseñarlo como se hacía en las comunidades, en contacto con la naturaleza, en la conversación, en el fogón...) (MR). In other words, the traditional structure of education in the Enlightenment rational society matrix is not compatible with the natural context of teaching Chedungun in the natural environment, in the walks, by the fire, through orality, etc. This aspect is reinforced by the opinion of another Mapuche educator: "I've always gone against the coordinator, because he's always asking us to do dynamics with guides, letters and numbers. Then the children will not learn that way. Because if the children ... if we are working with text guides, they won't be listening Chedungun. Because children have to hear the Chedungun language to learn, to listen to someone speak to them every day and they will go pouring words and words into your head and will be recording some words... easy words to them to listen. But if they are working with guides, they'll be focused on that. But without listening the teacher speaking Chedungun even if one speaks, they are concentrated doing their homework. It is not a strategy.

They ask me to, it must be done, because as they ... You have to let them ... As they know. They think it will be that way, but I think it is not that way. I am against the worksheet, pencils, anything. I'm against it" (Yo siempre me he ido en contra del coordinador, porque siempre nos están pidiendo que hagamos dinámicas con guías, con letras, con números. Entonces los niños no van a aprender de esa forma. Porque si los niños... si estamos trabajando con guías no van a estar escuchando el chedungun. Porque los niños tienen que escuchar el chedungun para aprender, que escuchar a una persona que les hable todos los días, y ellos van a ir vertiendo palabras y palabras en su cabeza y van a ir grabando algunas palabras que uno les... palabras fáciles que ellos escuchan. Pero si ellos están trabajando con guías se concentran en su guía no más. Pero sin escuchar al profesor hablar el chedungun. Aunque uno hable, pero ellos están concentrados haciendo sus tareas. Es que no es una estrategia. Igual me lo piden, pero hay que hacerlo, porque como que ellos... Hay que dejar que ellos... Como ellos saben. Ellos piensan que va a resultar de esa forma, pero yo pienso que no resulta de esa forma. Yo estoy en contra de la hoja, de los lápices, de nada. Estoy en contra de eso) (LP).

\section{Nobody owns chedungun: who can teach it?}

The above presents us with a language ideology around Chedungun not conceived as a system with objective existence, but as a product delivered by nature and part of being Mapuche. This has various implications regarding the various revitalization initiatives that are carried out not only in the communities described here, but also in different social spaces that the Mapuche (and other indigenous groups) currently occupy. This, from such language ideologies, then it follows that the owner of this cultural property is not a particular individual or entity, but it is a group heritage, that can be claimed as a right (a language right) in the processes of confrontation and resistance to the relationship between indigenous groups and the national society in the postcolonial era. That moves their demands from a purely linguistic area to a political or, more precisely, ethno political one: "... It is unthinkable to remain as a nation if we lose our language.... That is, all those demanding autonomy and self-determination are called to demand with the same force the learning, the revitalization of their respective languages" (... es imposible pensar en seguir siendo una nación si nosotros perdemos nuestro idioma.... O sea, todos los que demandan la autonomía y la autodeterminación están llamados a demandar con la misma fuerza el aprendizaje, la revitalización de los respectivos idiomas) (DC). But, who should therefore ensure the language?, who can claim to ownership, noting what is right or wrong in it or what changes must suffer so as to be adapted to new uses? In societies of enlightened rational tradition, where speakers of Indo-European languages such as English or Spanish are included, this question has an easy solution: nobody denies the role of scientific experts in the language or teaching (linguists, teachers, etc.) or the role of the Academies and academic institutions relating to language planning around the language. From our initial training in school, we learn to consider them as authorities and custodians of good views of what our languages are. However, in the case of Chedungun, associated with their particular cultural conception, the answer is not so clear. This is a crucial point when trying to use the school as a space for teaching the language (L2 mode) and the culture of indigenous communities. Since, how do we define and legitimize the "experts"? One possible answer to this need could be turning to a fundamental institutional framework in our rational Enlightenment tradition, as we pointed out: the academy. Indeed, in institutional terms, in the last decade, the agenda for the recovery of indigenous languages in Chile has been strongly marked by the aspiration of these communities (or rather some factions of them) to install local language academies, following the model of Academies of the Spanish language as that they would be responsible for ensuring this group heritage. In the case of the Mapuche language, this initiative was developed decades ago and still has no positive result. Certainly, those who originally installed the academy were intellectuals and Mapuche leaders trained in Linguistics ${ }^{23}$ and therefore, promoters of an ideology of the standard language, so it was not problematic for them to think of an institution formed by specialists to ensure the development of the language, with tasks such as language development, standardization, lexical development, formal styles, etc., but also measures to raise its social status. However, this vertical vision of ownership of the language seems to conflict precisely with the local way of understanding it, with this particular language ideology that makes of each speaker, while Mapuche-pehuenche kimün bearer, a valid representative to decide over their own language. This conflict was reflected in the general discussions that activists did at the time about this initiative, accusing an attempt of "privatization" of a collective heritage..$^{23}$ This, because in the absence of a language as an object that is reified, these kinds of initiatives are understood as attempts of "privatization" of this cultural resource, which undermines their collective rights: "...Conadi presented a proposal of a huge pretentious level, a kind of Royal Spanish Academy with a whole elitist bias only for academics, who of course Conadi... would qualify or accept as such" (... se presentó desde Conadi una "propuesta" de un nivel pretencioso descomunal, una especie de Real Academia Española con todo un sesgo elitista sólo para académicos que por supuesto Conadi... calificarían o aceptarían como tales) (LA).

This critical approach also relies on the questioning of experts in the language, something that is crucial when understanding the problems the IBE faces in the classroom, as it defines who should have the custody of the language, who are the authorities and after all, who owns it. Since Chedungun comes from nature, it is installed as a collective right, inherent to being Mapuche-Pehuenche and therefore, it belongs to all of them. Thus, the criteria and requirements to be considered "specialist" do neither come from scientific support, nor 
criteria alien to their culture, delegitimizing immediately the academic "experts", as this speaker stated:

"They talk about the brothers who run the initiative of the academy, but what about ourselves. Well, we are the ones who must take into our hands the solution from within, we are the Mapuche nation, not proponents of academia, gentlemen" (Hablan de los hermanos que dirigen la iniciativa de la academia, pero que pasa con nosotros mismos. Pues bien, somos nosotros quienes debemos tomar en nuestras manos la solución, desde dentro, nosotros somos la nación mapuche, no los propulsores de la academia, señores) (EK).

However, the Chilean government and the academic world are not and have never been willing to cede this autonomy to the communities. Therefore, it is clear that this conflict between language ideologies is ultimately a political struggle. At the local level, in the application of IBE in communities, the traditional educator has a clear lower status than the (university) teacher and it must always act under the custody and supervision of the "mentor" teacher. This scheme prevents, for example, as an educational resource leverage the knowledge and skills that other less skilled officials at school (such as janitors, drivers and cooks, who are precisely the ones who know the most and dominate the Chedungun more than any (university) teacher, who do not know the language. At the global level, beyond the reality of the communities, we can find many cases where academic and government institutions prove their vocation to replicate their own cultural logic in the way they have tried to "contribute" to the revitalization indigenous languages like Chedungun, ignoring their ownership and authority model on the language. For example, in 2008, a major national university developed a Diploma programme to enable as "specialists" a group of Mapuche people in the Metropolitan Region. And following the Western linguistic theory about language, the way to do it was through giving them tools from the Linguistics field, as stated by its Director, referring to its target audience: “... they are people who did not have basic tools of language theory, communication theory and applied linguistics to indigenous language teaching and it gave them all those tools" (...son personas que no contaban hasta ese momento con herramientas básicas de teoría del lenguaje, teoría de la comunicación o lingüística aplicada a la enseñanza de una lengua indígena, y lo que se hizo fue darles todas esas herramientas) (AN).

Thus, according to this model, what was needed was to transform the Mapuche people into "specialists" in linguistics to be authorized voices in their language. However, as we have seen, in Chedungun this figure does not seem acceptable or necessary.

A similar act of projection of western linguistic ideology, particularly with regard to the authority of the language, was expressed in the discourse of a (non-Mapuche) linguist when participating in 2013 in the presentation of a book for teaching Mapudungun. In one instance, where the target audience was Mapuche groups, what this scholar did was to project the vertical relationship between language, speaker and specialist that the notion of specialist in Linguistics guided by the ideology of standard- language implies: “... it is essential to have technical knowledge, specialized knowledge of phonology, grammar, semantics, the discursive level of language (...) this concern for a serious knowledge of the language, is something I insist, these are things that sometimes you cannot directly see when reading the book, but it's something that sustains it, that which gives it a base, it is what allows this text to have the background, the foundation that one can note when you read it" (...es fundamental tener un conocimiento técnico, un conocimiento especializado del conocimiento fonológico, de la gramática, de la semántica, del nivel discursivo de la lengua (...) esa preocupación por un conocimiento serio de la parte de la lingüística, es algo que insisto, son cosas que a veces uno puede no ver directamente cuando está leyendo el libro, pero es aquello que le da sustento, aquello que le da una base, es aquello que permite que este texto tenga el fondo, el fundamento que uno puede observar cuando lo lee) (GV).

However, this does not mean that in these communities the existence of specialists in language is not recognized. They are classified as kimches (sages, in their language and culture), as traditionally validated subjects as experts in culture. The point is that the criteria for such validation have nothing to do with formal education or scientific validation. Their validation as an expert and 'wise' opinion runs in another direction: “... they call him a wise man because he knows the language, he knows the culture (...) It depends independently of each one of them, it depends of each kimche, the sage, of the materials and didactics and the way he will teach... the kimche has the final decision" (... le dicen sabio porque sabe idioma, sabe de la cultura (...) Depende autónomamente de cada uno de ellos depende de cada kimche, del sabio, del material y la didáctica y la forma como va a enseñar.... la decisión final la tiene el kimche) (ACH).

The question, then, is this wise person an ignorant for not knowing of linguistics or teaching? It is precisely the figure of this native specialist that causes major drawbacks when implementing IBE programs trying to revitalize indigenous languages through school. ${ }^{15,32}$ By being an authority figure extracted from its natural context of legitimation (the community) and be transferred to an artificial scene of education school it loses all their natural attributes and is reduced to a minor character, by not possessing the keys to being considered an authority: he has not studied in formal education or pedagogy and linguistics and does not speaks standard Spanish (but one fraught with interference from Chedungun), so it even raises teasing from the students towards him, as stated by the principal of the Ralco high school. Thus, the vicious cycle of reproduction of a negative and stigmatized view of everything that relates to indigenous knowledge assessment has closed, reinforcing the message among students at a point where it becomes apparent that the lack of visibility of these and other ideologies must be overcome.

\section{Conclusion}

We have shown the assumption that the school can be a legitimate and entitled space for the teaching of Chedungun or other indigenous languages is not of common sense. That is the great problem of this and other revitalization initiatives. The resistance and conflicts that the implementation of the IBE faces in the studied Pehuenche communities do not only have to do with management issues, resources or skills of educators and students. Leaving aside the cultural models associated to indigenous languages that lead to parents, guardians and students to be in favor ('the language has an identity value', such as in places like Callaqui or Pitril, characterized by a greater displacement for Spanish) or against ("the indigenous language is a factor of discrimination and Spanish is a factor of social and economic success', as happened in the town of Trapa Trapa, characterized by greater conservation of Chedungun) the incorporation of indigenous languages in the school curriculum language ideologies that might call for a more superficial level - there is another group of language ideologies, deeper rooted that come into play when implementing programs like this. They 
are language ideologies that present challenges much more complex than expected, at the time,for example, to define who is responsible authorized for the transmission of this cultural knowledge: can a native, derived from the legitimacy that has in the community, be the authoritative voice to do so, but that lacks university education to do so? So far, the response of the program, derived from the language ideology (western, based on the ideology of the standard language, of colonial and post-colonial inspiration) of those who have formulated and implemented it (public policy designers, experts in curriculum, education researchers, linguists, anthropologists, etc.), has been negative, in part because they have assumed as necessary that there should always be a "mentor" teacher (i.e, graduated from the university) who accompanies and watches over the work of the traditional educator .

This feature alone is already reflecting a significant ideological struggle, which is the result in part of the dominant society us in such a way that reproduces perfectly the colonialist and evolutionist logic that the same program aims to reverse. The native, as an expert, does not have no autonomy, no voice, nor can it raise issues that, according to their knowledge and kimün, seem relevant to cover the dimensions that family agencies have stopped covering. Furthermore, the educator has a total lack of empowerment as a figure of pedagogical in front of students, thus the contents he expresses cease to be significant. Thus, the lack of consideration related to the contents regarding the indigenous culture and language is reinforced. Another specific area in which these ideological conflicts are reflected is the way in which the contents of indigenous language and culture are taught: one morning, we were invited to a trawün by the Principal of Pitril School. This was carried out in the backyard of the school (surrounded by Araucaria trees and streams, on the slopes of a hill) in which students would sit and listen to a dialogue with the elders of theirs and other communities about the language and culture. This activity may have been perfectly well suited for the traditional way of transmission of the language and culture; however, it had no place within the curriculum framework of the school system and was no more than an isolated phenomenon, impossible to be reproduced systematically either there or elsewhere.

The analysis of this and other situations that occur in the context of the teaching of indigenous languages within the IBE from the point of view of language ideologies, allows us to return to the original question of the article that, anecdotally, allowed to introduce the topic and the proposed approach and answer it: as in Spanish, to say that the word "arrendamiento" does not exist and is misused, or that it should be said "hubo" or "hubieron", or that a word is stressed in this or that syllable, etc., they are all options that are culturally created and therefore are ideological, so what is worth analyzing is what is the language ideology, about the indigenous language in question, I intend to represent and if this one is or is no legitimized within the community in which I stand. Therefore, the challenge is open in the sense that everyone working around language whether indigenous or not take in this cultural dimension of their conceptions and practices involved. Not doing so would take into a resounding failure (beyond filling headlines and figures in State statistics) many of the attempts to address social, political and economic asymmetries in the contact of indigenous languages with languages of power (Spanish or English), helping to reproduce a social segregation and discriminatory system for languages and people. It is not therefore, a solely academic imperative (it is a vast field that has not yet been explored), but above all an ethical one.

\section{Acknowledgements}

None.

\section{Conflict of interest}

Author declares there is no conflict of interest in publishing the article.

\section{References}

1. Silverstein M. Language Structure and Linguistic Ideology. In: Clyne P, et al. editor. The Elements: A Parasession on Units and Levels, Chicago Linguistics Society, USA; 1979. p. 193-247.

2. Irvine J, Gal S. Language ideology and linguistic differentiation. In: Kroskrity P, editor. Regimes of language: Ideologies, polities and identities, School of American Research Press, Santa Fe, USA; 2000. p. $35-84$.

3. Kroskrity P. Regimes of Language: Ideologies, Polities and Identities. School of American Research, USA; 2000. p. 432

4. Makihara M, Schieffelin B. Consequences of Contact: Language Ideologies and Sociocultural Transformations in Pacific Societies. Oxford UP, UK; 2007. p. 248.

5. Hill J. 'Expert Rhetorics' in Advocacy for Endangered Languages: Who is listening and what do they hear? Journal of Linguistic Anthropology. 2002;12:119-133.

6. Cameron D. Language Endangerment and Verbal Hygiene. In: Duchene A, Helller M, editor. Discourses of Endangerment, Continuum, UK 2007. p. 268-285.

7. Sepade. Diagnóstico participativo comuna Alto Bío Bío. Municipalidad de Alto Bío Bío, Chile; 2004. p. 136.

8. Gunderman H, Canihuán J, Castillo E, et al. Perfil sociolingüístico de comunidades mapuche de la VIII, IX y X región, Fondo de Cultura y Educación, Chile; 2008. p. 181.

9. CONADI. Catastro de hablantes de las asociaciones indígenas mapuche de la Región Metropolitana, Fondo de Cultura y Educación, Chile; 2010. p. 153

10. Espinosa V. El aymara en la Región de Arica y Parinacota. Boletín de Filología. 2009;44(1):39-53.

11. Gundermann H, Gonzalez H, Vergara J. Vigencia y desplazamiento de la lengua aymara en Chile. Estudios Filológicos. 2007;42:123-140.

12. Gundermann $\mathrm{H}$, Canihuán J, Clavería A, et al. Permanencia y desplazamiento, hipótesis acerca de la vitalidad del mapuzugun. RLA. 2009;47(1):37-60.

13. Wittig F. Desplazamiento y vigencia del mapudungun en Chile: un análisis desde el discurso reflexivo de los hablantes urbanos. $R L A$ 2009;47:135-155.

14. Lagos C. Mapudungun en Santiago de Chile: representaciones sociales en los mapuches urbanos. RLA. 2012;50(1):161-190.

15. Lagos C. El Programa de Educación Intercultural Bilingüe y sus resultados: ¿perpetuando la discriminación. PEL. 2015;52 (1):84-94.

16. Eira Ch. Addressing the ground of language endangerment. In: David $\mathrm{M}$, et at. editor. Working Together for Endangered Languages: Research Challenges and Social Impact. Oxford, England; 2007. p. 82-98.

17. Kandler A, Unger R, Steele J. Language shift, bilingualism and the future of Britain's Celtic languages. Philos Trans R Soc Lond B Biol Sci. 2010;365(1559):3855-3864 
18. Henríquez M. Estado de la fonología segmental del mapudungun de escolares lafkenches de la comuna de Tirúa: rasgos prominentes. Literatura y Lingüística. 2016;34:295-318.

19. Wabgou M, Roth A. Las politicas públicas de las diversidades: identidades y emancipación. Universidad Nacional de Colombia, Colombia; 2009. p. 305.

20. Gallardo A. La situación mapuche, problema de planificación lingüística. Cultura hombre y sociedad. 1984;1:151-188.

21. Hernández A. Papel tuaiñ mapudungún meo! Un primer ensayo de ortografía práctica en mapudungún. Cultura hombre sociedad 1984;1:189-203.

22. Hernández A. Encuentro para la unificación del alfabeto mapuche Cultura hombre sociedad. 1986;3:195-210.

23. Lagos C, Espinoza M. La planificación lingüística de la lengua mapuche en Chile a través de la historia". Lenguas Modernas. 2013;43:47-66.

24. Gissi N. Los mapuche en el Santiago del siglo XXI: desde la ciudadanía política a la demanda por el reconocimiento. 2004.

25. Abarzúa L. Modelos culturales e ideologías lingüísticas tras las actividades de revitalización de la lengua aymara en Chile. Universidad de Chile, USA; 2016.

26. England N. Mayan Language Revival and Revitalization Politics: Linguists and Linguistic Ideologies. American Anthropologist. 2003;105(4):733-743.

27. Cru J. Shifting Language Ideologies among Young Maya Professionals: Overcoming Purism in Yucatán. Critical Multilingualism Studies. 2016;4 (2):111-132

28. Brody M. Tres épocas de la escritura maya, sus ideologías subyacentes y su influencia en lo actual. In: J Lizama, editor. El pueblo maya y la sociedad regional. Perspectivas desde la lingüistica, la etnohistoria y la antropología, Ciesas, USA; 2004. p. 29-50.

29. Abdelhay A, Asfaha Y, Juffermans K. African literacy ideologies, scripts and education. Cambridge Scholars, UK; 2014. p. 1-62.

30. Kelly P. The invention, transmisión and evolution of writing. Insights from the new scripts of west africa. 2017.

31. Donaldson C. The social life of orthografy development. Working Papers in Educational Linguistics. 2015;30(2):1-12.

32. Espinoza M. Contextos, metodologías y duplas pedagógicas en el programa de educación intercultural bilingüe en Chile: una evaluación crítica del estado del arte. PEL. 2016;54(1):27-39.

33. Deumert A. Language planning and policy. In: Mesthrie, et al, editor. Introducing sociolinguistics, Edinburgh University Press, UK; 2000. p. 384-418.
34. Ahearn L. Living Language: An Introduction to Linguistic Anthropology. Wiley Blackwell, USA; 2012. p. 368.

35. Kroskrity P. Language Ideologies-Evolving Perspectives. In: Jaspers J, editor. Language Use and Society. John Benjamins, Philadelphia, USA 2010. p. 192-211.

36. Errington J. Ideology. In: Duranti A, editor. Key Terms in Language and Culture, Blackwell, USA; 2001. p. 110-122.

37. Kroskrity P, Field M. Beliefs, Practices and Struggles in Indian Country. Native American Language Ideologies. The University of Arizona Press, USA; 2009. p. 336.

38. Schmidt R. Defending English in an English Dominant World: the Ideology of the "Official English" Movement in the United States. In: Duchene A, Helller M, editor. Discourses of Endangerment, Continuum, UK; 2007. p. 197-215.

39. Rourke B, Ramallo F. Competing Ideologies of Linguistic Authority Amongst new speaker in contemporary Galician. Language in Society. 2013;42(3):287-305.

40. Bauman R, Briggs Ch. Voices of Modernity. Language Ideologies and Politics of Inequality, Cambridge University Press, Cambridge, UK; 2003. p. 356.

41. Jaffe A. Misrecognition Unmasked? "Polynomic" Language, expert statuses and orthographic practices in Corsican Schools. Pragmatics. 2003;13:515-537.

42. Barrett R. Language Ideology and Racial Inequality: Competing functions of Spanish in an Anglo-owned Mexican Restaurant. Language in Society. 2006;35:163-204.

43. Schieffelin B. Introducing Kaluli Literacy: A Chronology of Influences. School of American Research, USA; 2000. p. 293-327.

44. Messing J. Multiple Ideologies and Competing Discourses: Language Shift in Tlaxcala, Mexico. Language in Society. 2007;36:555-577.

45. Ojeda P, Álvarez J. Elementos para la construcción social del chedungun a partir del discurso en torno a la lengua de hablantes bilingües de la VIII Región. Boletín de Filología. 2014;49(2):45- 61.

46. Kroskrity P. Discursive Discriminations in the Representation of Western Mono and Yokuts Stories: Confronting Narrative Inequality and Listening to Indigenous Voices in Central California. Journal of Folklore Research. 2013;50:145-174.

47. Jospeh J. Language and Politics. In: Davies A, Mitchell K, editors Edinburgh University Press, USA; 2006. p. 181.

48. Seargeant P. The historical ontology of language. Language Sciences. 2010;32:1-13. 